\title{
Seamless flipped learning: a mobile technology- enhanced flipped classroom with effective learning strategies
}

\author{
Gwo-Jen Hwang ${ }^{1}$ - Chiu-Lin Lai ${ }^{1}$ • \\ Siang-Yi Wang ${ }^{1}$
}

Received: 15 June 2015/Revised: 29 July 2015/Accepted: 29 July 2015/

Published online: 15 August 2015

(C) Beijing Normal University 2015

\begin{abstract}
The flipped classroom has been recognized by educators as an innovative and effective instructional approach. It totally overthrows traditional instruction by switching in-class instruction time with at-home practicing time. While the effectiveness of the flipped room has been identified, the challenges of applying it to school settings have also been pointed out, such as the need for effective in-class learning designs and the necessity of helping students learn across at-home and inschool contexts. In this paper, the challenges as well as the definition, characteristics, and educational objectives of flipped learning are introduced; moreover, the seamless flipped learning model is proposed by integrating the features of mobile and wireless communication technologies into the flipped classroom model to provide a guide for researchers and educators to develop effective flipped learning activities and plans for helping students learn seamlessly across contexts.
\end{abstract}

Keywords Flipped classroom · Mobile learning $\cdot$ Seamless learning $\cdot$ Learning strategies

Gwo-Jen Hwang

gjhwang.academic@gmail.com

Chiu-Lin Lai

jolen761002@gmail.com

Siang-Yi Wang

tiffany8135@gmail.com

1 Graduate Institute of Digital Learning and Education, National Taiwan University of Science and Technology, Taipei, Taiwan 


\section{Paradigm shifts in technology-enhanced learning}

Recently, the concept of education has greatly changed from teacher-centered instruction to diverse learner-centered learning modes. With such a change, teachers play the roles of not only knowledge providers, but also learning promoters who encourage students to construct knowledge actively. The flipped classroom has become one of the most emphasized and innovative teaching strategies in recent years. It overthrows the direct teaching in traditional courses and focuses on leading students to apply knowledge and to achieve higher level learning objectives.

The concept of the flipped classroom was proposed by Bergmann and Sams (2012). They recorded class lectures and provided the videos online to enable students to watch and review the teaching contents more conveniently. With such a strategy, significant results were obtained, which inspired them to further employ it (i.e., instructing via online videos) before classes. In this way, students could prepare for classes by watching the videos and could thus form the basic knowledge before class. Consequently, more in-class discussion or practice could be conducted to engage students in more in-depth learning and help them clarify any misconceptions (Bergmann and Sams 2012).

There are diverse definitions of the flipped classroom. One of the most common is "Recording in-class activities to convey a course: Students watch the video before the class and use the class time to solve complex concepts, answer questions, and students are encouraged to learn actively as well as create bonds with daily lives" (Stone 2012). However, other scholars believe that the way of self-learning before class is not only confined to videos or the Internet. As long as proper learning contents and suitable guidance are offered to the students, similar learning objectives could be achieved (Kim et al. 2014).

In flipped classrooms, the teacher's role should be guiding students to think and discuss, and to give professional feedback and advice. Good self-learning quality can lead to heated communication, discussion, and enhanced problem-solving ability. Therefore, in the process of the flipped classroom, students play the role of active learners and make good use of the assistance given by experts to elucidate relevant concepts. Teachers become facilitators and assistants, instead of instructors. With the increasing emphasis on the concepts of the flipped classroom, the ideas of technology teaching have shifted from the application at school to self-learning at home. The self-practice and homework at home become the interaction among peers, students, and teachers at school.

Furthermore, most noteworthy is another terminology: Flipped Learning, which focuses on the use of effective learning methods to engage students in more practice and interactions in the classroom. Unlike the definition of the flipped classroom: "The original instruction at school moves to at home and the homework part moves to school," the Association of Flipped Learning Network (2014) officially proposes the following definition of flipped learning: "Flipped Learning is a pedagogical approach in which direct instruction moves from the group learning space to the individual learning space, and the resulting group space is transformed into a 
dynamic, interactive learning environment where the educator guides students as they apply concepts and engage creatively in the subject matter."

While many applications have demonstrated the benefits of flipped classroom and flipped learning in helping students learn effectively in school settings, educators have indicated the importance of engaging students in real-world learning tasks (Hwang et al. 2008). Therefore, in this paper, the model of seamless flipped learning is proposed. Moreover, the principles and strategies of developing seamless flipped learning are provided as well. Following the proposed principles and strategies, school teachers can develop effective learning activities to guide students to learn seamlessly and effectively, and in particular, linking what they have learned in schools to what they have experienced in daily life. More importantly, the notation of incorporating the concepts of seamless learning into flipped learning could inspire researchers and educators to consider technology-enhanced learning as well as flipped leaning from new perspectives.

\section{Characteristics and challenges of the flipped classroom and flipped learning}

Stone (2012) stressed that educators need to make extra efforts in order to meet the expected outcomes of the flipped classroom. Students' opinions and learning status can be widely accepted by educators through flipped learning. Drawing together the ideas of different scholars, the following characteristics of the flipped classroom are proposed (Abeysekera and Dawson 2014; Bishop and Verleger 2013; Kim et al. 2014):

(1) Changes in the usage of class time: Those teaching contents that were traditionally taught through direct instruction and can be understood by students themselves are provided in other forms, such as video, for students to learn outside the classroom. Besides, in-class discussion, projects, and problem solving are included in the class to help students apply what they have learned and to cultivate their analytical and judging abilities.

(2) Changes in the usage of time outside the class: The time used to do homework is moved to the class time. Different ways of self-learning, such as watching videos, are scheduled before the class time.

(3) The time outside the class time is designed for students to gain knowledge at the remembering and understanding levels.

(4) Peer interaction, student-teacher interaction, and problem-solving skills are emphasized in class. Students gain knowledge at the applying, analyzing, and evaluating levels.

(5) Technology is used, especially video. While some scholars have argued that technology is not a necessary element for self-learning before class time, undeniably, it is the easiest way to present teachers' instruction of the learning contents. Besides, teachers can manage the video and teaching materials for students more conveniently through teaching platforms or other 
online systems, and have interaction with students before and after class. Therefore, technology benefits the implementation of the flipped classroom.

In short, the flipped classroom is a pedagogical approach which moves the learning contents taught by teachers' direct instruction to the time before class in order to increase the chances for the students and teacher to interact. Therefore, teachers would have more time to guide the learning activities and solve students' problems in order to promote the learning effects.

The leaders of flipped learning argue that the implementation of the flipped classroom can bring effects of flipped learning, but it is not guaranteed. Teachers' preparation is the key element. Some teachers have already used some methods to flip the class, for instance, letting students learn outside the class, offering video clips as supplementary materials, and cultivating the students' problem-solving abilities. However, more requirements need to be met to achieve flipped learning. In other words, "flipped learning" is a higher level and stricter definition of the "flipped classroom." In this paper, the two terminologies are not strictly distinguished. The emphasis is on the organization and good implementation of the flipped classroom to attain the real effects of flipped learning.

There are many examples of adopting the concept of the flipped classroom in educational settings (e.g., Chao et al. 2015; Fautch 2015; Hung 2015). Early applications are the chemistry course taught by Jonathan Bergmann and Aaron Sams, and Salman Khan's teaching video to solve relatives' children's learning problems. The online video was not limited by time and space and unintentionally benefited students whose academic performance was lagging behind that of others; thus, this online video teaching system became the famous "Khan Academy." Because of its popularity, the Khan Academy has collected many teaching videos from different subjects. Learners are able to learn online according to their own pace and review unfamiliar content. Taking advantage of technology to realize the concept of individualized teaching, Khan has been invited to share his thoughts about the management of the teaching platform and the advantages of video teaching, giving even more emphasis to the student-centered "Flipped classroom" (Khan 2015).

Many applications have stressed that the flipped classroom is the objective of the course design. For instance, Gilboy et al. (2015) used a flipped classroom in a nutrition course. While organizing the curriculum, they divided the learning content into three stages: before class, in class, and after class. In the before-class stage, the teacher uploads the video containing basic knowledge and concepts to the learning platform. Students need to preview the learning contents, search for related information on the Internet, and write down the questions they encounter. In the inclass stage, the teacher and students have face-to-face interaction and discussion of these questions. The students are given individualized guidance to clarify misunderstood concepts. Besides, they are divided into groups and conclude the learning contents to reinforce their memory by exchanging opinions. In the afterclass stage, students are given a pencil-and-paper test to assess their learning status. The results show that with this teaching approach not only students' learning results are increased, but also both the students' and the teacher's satisfaction with the 
course tends to be high. Scholars have indicated that the difference between this teaching method and traditional teaching is to move the content and homework originally after or in class to the time before class, letting students watch the video about teaching contents and basic knowledge before class as well as practicing and reflecting in class. Students can not only avoid passively accepting knowledge from instructors, but can also improve their critical thinking and higher level problemsolving skills (Francl 2014).

The implementation of flipped learning is not static. The abovementioned three stages can be done and managed differently. One flipped classroom example in the USA is applied in a chemistry course. The teacher divided the curriculum into three stages. In the first stage, every student must watch the video recorded by the teacher before the class and answer the designated questions, so that these can be the reference for the following in-class teaching. In the second stage, the teacher spends 15 min reviewing the important concepts of the contents and guides the students to discuss any high-error-rate questions. The third stage takes about $50 \mathrm{~min}$, which is the greatest proportion of the time. Each group comes up with a result and the teacher gives feedback based on the answers. Hence, students are asked to propose extended questions. In this flipped learning activity, the teacher used group discussion and let students continuously think about what they had learned. From the quantitative results, through flipped learning, students' academic performance and learning confidence were increased. Besides, students' problem-solving ability and the attitude of being responsible were also improved (Fautch 2015).

Flipped learning can be divided into these stages. Furthermore, based on previous experience, scholars have also summarized some principles of class design, including taking advantage of technology, providing proper guidance and rewards, preparing students' prior knowledge before class, planning enough in-class activity time, and boosting peer interaction by teamwork (Kim et al. 2014; Ng 2015).

Researchers have indicated some of the reasons why flipped learning has been adopted by so many educators (Bergmann et al. 2011; Francl 2014; Lasry et al. 2014).

(1) Teachers should make good use of the multimedia technology to provide students with teaching materials and allow them to learn without time or space limitations. Students are taught to collect information before class and are expected to be active learners responsible for their own learning.

(2) The teaching video allows students to review and preview to have profound prior knowledge before class, and lets those students who miss classes catch up.

(3) Multimedia digital teaching materials are easy to save, manage, revise, and impart.

(4) In the process of preparing a flipped classroom, educators can inspect and reflect on the whole curriculum and improve the teaching contents and activity design.

(5) With enough prior knowledge, students have more time to conduct higher level activities and questions. Educators can further provide individualized 
consulting, which benefits students with learning difficulties the most, and teachers would better understand the learning status of their students.

(6) In-class activity and discussion can increase teacher and student as well as peer interaction. An active atmosphere can improve students' learning motivation and, through peer pressure, the learning effects would increase.

(7) More teaching strategies, such as project-based learning and problem-solving learning, can be imported into the classroom to promote higher order thinking abilities, which would be more meaningful.

Although teachers do not have to prepare those traditional teaching contents, the workload would still be more challenging due to the individualized teaching. More in-depth discussion and topics with interaction need to be designed. Therefore, the educational value of flipped learning is to let students apply what they have learned with the teacher's guidance. Students would be more active in the class and their higher order thinking ability would be cultivated (Spencer et al. 2011; Francl 2014). Besides, the increasing population of online social networks helps realize the concept of individualized teaching and enables teachers to discuss and answer every student's questions. More time is used for online and in-class discussion, which helps students clarify the ideas and boosts student/teacher as well as peer interaction. Through peers' influence, students with low academic performance can increase their learning speed (Bergmann and Sams 2012; Tucker 2012).

Certainly, being a pioneer of flipped learning needs both time and effort. Teachers need to inspect the teaching contents and analyze the essence and objectives of teaching, which can use technology and teaching strategies more appropriately. Therefore, to successfully adopt flipped learning, teachers must have strong teaching beliefs and learn the experience and knowledge of curriculum analysis and activity design to let students understand the real meaning of learning and to achieve the expected outcomes of flipped learning (Bergmann et al. 2011).

Another problem of using traditional computers and communication technologies to support flipped learning is that students are not able to learn seamlessly. They might spend much time studying the learning materials and making annotations at home; however, they cannot take all of the learning materials with their annotations to school, not to mention reviewing the lesson while commuting between home and school.

\section{Seamless learning}

Wong et al. (2015, p. 10) defined seamless learning as "when a person experiences a continuity of learning, and consciously bridges the multifaceted learning efforts, across a combination of locations, times, technologies or social settings." Milrad et al. (2013, p. 95) indicated that "Cross-contextual learning can enable a continuous learning experience across different settings, such as home-school, or workplace-college." Several researchers have further pointed out that mobile devices and wireless networks are such technologies which enable students to learn continuously across different contexts (Wong 2012; Wong and Looi 2011). Such a 
mobile technology-enhanced learning approach has been called "mobile seamless learning" by researchers to represent the fact that students are able to smoothly switch from one learning scenario to another using mobile devices (Milrad et al. 2013).

In the past decade, seamless learning has been widely discussed by researchers from different aspects. One aspect is "the seamless connection between formal and informal learning" (Wong et al. 2010), which emphasizes the need to design both in-school and out-of-school activities and encourage students to apply what they have learned in school to their daily-life problems as well as raise questions in class based on their daily-life experiences. For example, Wong et al. (2015) proposed the MyCLOUD (My Chinese ubiquitOUs learning Days) model, which aims to bridge the formal and informal aspects of Chinese language learning by supporting students to learn in both the in-school and out-of-school learning spaces. Kong and Song (2014) further indicated the importance of pedagogical design for improving students' domain knowledge gains and inquiry skills in seamless learning activities.

Another widely discussed issue of seamless learning studies is related to how technologies can be used to support students' seamless learning (Looi and Wong 2014). For example, Looi et al. (2010) reviewed the potential of mobile learning studies for designing seamless learning environments and proposed several suggestions for researchers. Later, Wong et al. (2012) reported a mobile-assisted Chinese language learning approach that engaged students in contextualized learner content creation and meaning making with their daily-life experiences. Recently, Song (2014) reported the "Bring Your Own Device (BYOD) for seamless science inquiry" project, which was conducted in an elementary school in Hong Kong. They found that the students who used their own mobile devices to learn seamlessly had good learning achievement and revealed a positive attitude toward the seamless science inquiry (Kong and Song 2015).

The concept of seamless learning, i.e., "learning across contexts seamlessly," has good potential for strengthening the scope of flipped learning by extending students' learning space from home and school to their daily-life contexts.

\section{Seamless flipped learning—definition and educational objectives}

In this paper, we aim to define the concept of seamless flipped learning by applying the notation of seamless learning to the extension of flipped learning via using mobile and wireless communication technologies to seamlessly connect at-home learning, in-class activities, and in-field learning; that is, a flipped classroom assumes learning across the home/classroom spaces, whereas seamless flipped learning occurs seamlessly across multiple contexts, physical and social spaces. As shown in Fig. 1, by taking into account the component of students' planned and emergent learning outside school, teachers can design learning activities to engage the students in field trips, such as a visit to a butterfly farm or a school garden; that is, teachers play the role of leveraging the diversity of ideas or prior experiences of students outside the classroom to facilitate the classroom discussion. To help teachers develop effective activities for guiding students to learn in different 


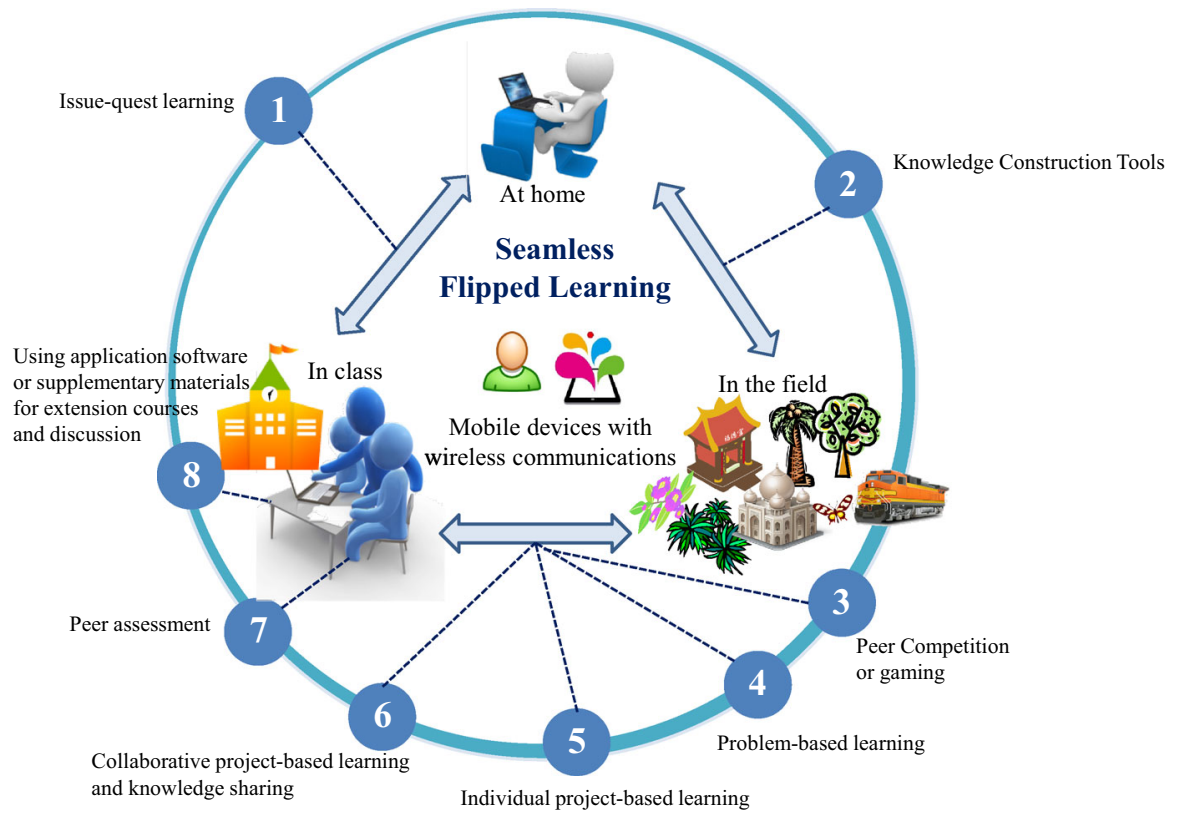

Fig. 1 Notation of seamless flipped learning

contexts, Fig. 1 also presents eight learning design strategies. The details of individual strategies are introduced in the next section.

In a seamless flipped learning environment, there are a diversity of ideas that the students and teachers can explore, and the teacher can help the class converge on the important curricular ideas. For example, in the nutrition unit of a health course, the teacher can ask the students to work in groups to think about what causes obesity. To respond to the teacher's request, the students might try to collect "evidence" from websites or books; alternatively, they might want to interview peers and friends or take pictures (e.g., of oily food) using their mobile phones. The teacher can also ask the students to upload their evidence on a common site (e.g., Google Sites) to share and categorize what they think causes obesity. In class, the teacher could get the groups to argue the various ideas on obesity or peer critique another group's common site. This would foster emergent learning as students critique and discuss each other's ideas.

In such a seamless flipped learning environment, mobile devices and wireless communication facilitate the continuous flow of learning in different contexts, physical and social spaces. For example, with the help of mobile devices, students can bring the annotations and notes they made as well as the data they collected at home or in the field to their classes at school. They can even review the learning content or do practice on the way to and from their home and school. Moreover, learning can also be emergent as students observe science phenomena which may pique their interest so that they are engaged in asking questions. 
The educational objective of seamless flipped learning can be addressed based on the Taxonomy of Educational Objectives proposed by Bloom (1994) and modified by Anderson and Krathwohl (2001). There are six levels: knowledge, comprehension, application, analysis, synthesis, and evaluation. As shown in Fig. 2, in flipped learning, what students do before and after the class belongs to remembering and understanding, that is, the lower levels of cognitive learning. Instruction from video is used to express the basic contents of the target subjects. In class, the higher levels of cognitive learning are cultivated, such as applying, analyzing, and evaluating (Francl 2014). From the figure, it is evident that the teacher's role in the class shifts from being an instructor to a learning facilitator and a problem-solving counselor. They can use in-class discussion, collaborative learning activities, individual guidance, and other strategies to promote students' self-reflection ability to help them attain higher levels of cognitive learning behavior, such as applying, analyzing, and evaluating (Spencer et al. 2011).

On the other hand, aiming at those higher level abilities, international organizations such as UNESCO, the E.U., and the OECD have recently been placing special emphasis on the curriculum development of the "core competencies" in education. These core competencies stress how to improve students' knowledge, abilities, and attitude, and how to let them experience thorough development to face the challenges brought by twenty-first century globalization. Communication, Collaboration, Critical thinking, Complex problem solving, and Creativity are deemed to be the twenty-first century core competencies (Lai and Hwang 2014; Trilling and Fadel 2009).

One of the objectives of flipped learning is to promote self-directed learning. With the help of mobile and wireless communication technologies, seamless flipped learning is a more student-centered approach which can foster their self-directed

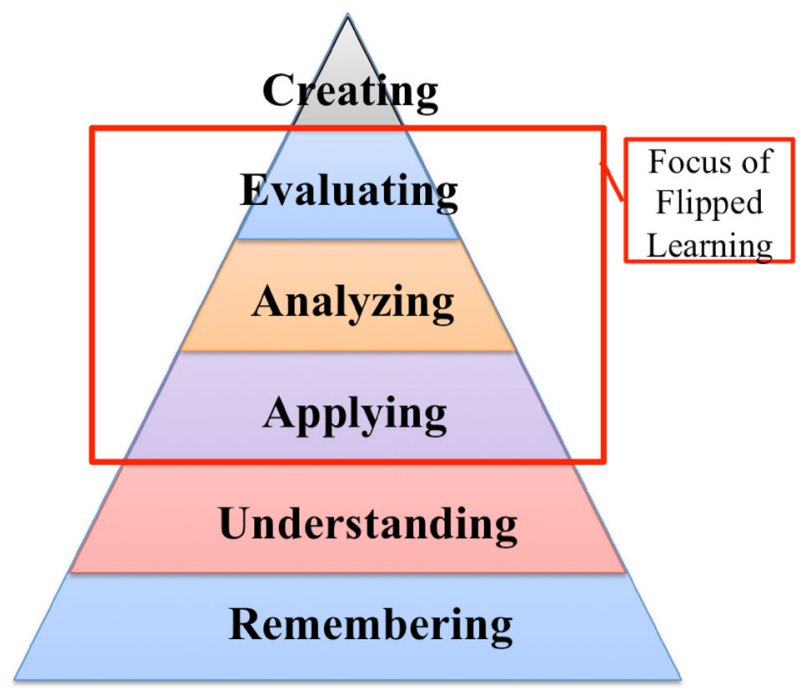

Fig. 2 Educational objectives of in-class activities for flipped learning 
learning through student agency. This implies that seamless flipped learning could be a viable and better alternative to achieve the abovementioned five competencies, abbreviated as the $5 \mathrm{C}$ competencies, than the traditional Flipped Learning approach or mobile technology-enhanced learning. In the following, the relationships between seamless flipped learning and the $5 \mathrm{C}$ competences are addressed in detail.

\section{Communication}

"Communication" refers to the competence of presenting and exchanging ideas with others and making reflections accordingly. Many studies have noted that there are connections among effective communication, students' achievement, and students' satisfaction with teaching (Good and Brophy 2003), indicating the importance of their communication ability. Engaging students in seamless flipped learning implies that the students are encouraged to communicate with their peers and teachers across various learning spaces, including at-home, in-class, and in-field learning. With a proper learning design, students' communication competence is likely to be improved by participating in issue-based peer-to-peer and peer-toteacher interactions across contexts based on what they have learned from the instructional videos and what they have collected and observed in the field.

\section{Collaboration}

Collaborative learning is a learning type to achieve a mutual goal through teamwork (Kamarudin et al. 2012; Rooij 2009). In this competitive twenty-first century, few jobs can be done independently. Many projects need to be completed through the cooperation of teamwork (Kamarudin et al. 2012). In a seamless flipped learning environment, teachers can use different strategies to boost students' development of collaborative skills, such as project-based learning tasks that require the students to learn basic knowledge from instructional videos at home, collect data from in the field, and design the artwork together in class.

\section{Critical thinking}

Critical thinking is a cognitive process which involves the understanding of problems and ideas, drawing conclusions, and proposing solutions as a result of analysis and judgment (Felder and Brent 2003). The cultivation of the ability of critical thinking is an important educational objective which enables students to understand and judge complex information and to make proper decisions (Dwyer et al. 2014; Glassner et al. 2005; van Gelder 2005).

Woolfolk (2004) pointed out that, while developing critical thinking, students should adopt appropriate practices, such as defining and clarifying questions (including making clear the core issue and problems, comparison of similarities and differences, decisions of related information, and formation of proper questions), judging problem-related information (including distinguishing truth, opinions, and inferences; checking consistency; finding unstated hypotheses; recognizing stereotypes and clichés; seeing clearly bias and emotional factors; and judging different 
values and consciousness), and problem solving as well as conclusion formation (including recognizing the appropriateness of the information and possible result prediction). Therefore, while planning seamless flipped learning activities, teachers can guide students through the critical thinking process mentioned above; that is, defining and clarifying questions via watching instructional videos at home and searching for supplementary information using mobile devices, judging problemrelated information via online discussion, solving problems via collecting evidence in the field or on the Internet, and summarizing findings and making conclusions via discussing in class.

\section{Complex problem solving}

Complex problem-solving ability means that students use the gained knowledge and propose a solution based on their understanding of the problem. Scholars suggest that the cultivation of such ability needs to include a number of processes: identification of problems, presentation of problems, strategy selection, implementation strategy, and result assessment. To complete the processes, besides the knowledge in certain fields, good analytical and judging abilities are needed. Furthermore, after assessing the results, students should be able to explain their thinking logic (Eggen and Kauchak 2007). In a seamless flipped learning activity, teachers can guide the students to solve the specified problems following the process using mobile technology across various learning spaces; for example, identifying problems by watching instructional videos at home and collecting relevant information in the field, presenting problems to peers and teachers in the class and selecting a strategy, implementing the strategy in the field, and evaluating the result in class.

\section{Creativity}

Creativity is an ability to make, refine, or use other ways to solve problems (Eggen and Kauchak 2007). Just like learning, it needs prior knowledge as the background (Simonton and Ting 2010). The richness of knowledge in a certain field is the basis of creativity (Woolfolk 2004), and a fertile imagination is essential. It is a very complex cognitive process and is related to the environment. Many scholars deem it to be a productive exploring process (Finke et al. 1992). In a seamless flipped learning activity, students' creativity and imagination ability can be improved by engaging in a creative project, such as developing a website or an innovative artwork, by searching for relevant information on the Internet, making observations in the field, and participating in brainstorming in class or on their mobile devices.

What is noteworthy is that the $5 \mathrm{C}$ competencies are closely related to such an extent that there is no need to distinguish which ability is being cultivated. For instance, communication ability can be enhanced through cooperation. Meanwhile, through good communication, collaboration can be improved and can enhance the team spirit. In collaborative learning, students can experience critical thinking through peer interaction and provide better viewpoints to solve complex problems or complete projects. Through the integration of the $5 \mathrm{C}$ competencies, students' knowledge, abilities, and attitudes can complement one another. 


\section{Principles and strategies for seamless flipped learning}

Wong and Looi (2011) indicated that the success of mobile technology-supported seamless learning heavily depends on teachers' learning designs. They emphasized that it is important to engage students in an "enculturation process" to adapt their original beliefs, attitudes, and learning methods to the status of learning seamlessly by considering mobile technology-supported learning activities as part of the formal curriculum. This implies that teachers should develop teaching plans to encourage students to learn in informal and out-of-school contexts; more importantly, the students need to learn to apply what they have learned in school to deal with reallife problems as well as discuss those issues related to their daily-life experiences in the formal curriculum. Accordingly, there are several principles for school teachers to develop seamless flipped learning:

(1) Engaging students in self-learning at home: Teachers need to provide students with instructional materials, such as instructional videos, before the class time. The instructional content in the videos is mainly designed for students to gain knowledge at the memorizing and comprehending levels.

(2) Designing in-field learning activities to encourage students to apply what they have learned to real-world problems as well as collecting information from daily-life experiences. The in-field learning tasks mainly focus on learning the knowledge at the applying, analyzing, and evaluating levels.

(3) Designing in-class learning activities to engage students in higher order thinking based on what they have learned from the instructional videos and what they have observed or collected from the field trips or their daily-life experiences. The in-class learning activities might focus on the applying, analyzing, evaluating, or even creating levels, depending on the objective of the course unit.

(4) Encouraging peer-to-peer and peer-to-teacher interactions in all learning spaces, that is, home, school, and other real-world spaces.

(5) Mobile and wireless communication technologies are used to seamlessly connect the self-learning at home, exploration and application in the field, high-order thinking tasks in the class, and peer-to-peer and peer-to-teacher interactions across these learning spaces.

To assist teachers in planning effective in-class and out-of-class learning activities for seamless flipped learning, in this study, eight learning strategies are proposed.

\section{Issue-quest learning}

In an issue-quest learning activity, the teacher selects an issue related to the learning content and lets students discuss and raise questions according to that issue (Kuo et al. 2012; Kuo and Hwang 2014; Lan et al. 2012; Tsai et al. 2012). The activity can be conducted for individuals or in small groups. Before the teaching activity, 
teachers need to collect relevant supplementary information such as articles or videos related to that issue. At the beginning of a seamless flipped learning activity for issue quest, the students are asked to watch the videos and the supplementary materials provided by the teacher. Following that, they need to collect information on the Internet or evidence from the real world to support their points about the issue when discussing with peers in the classroom.

The selected issue must be related to the learning content; moreover, it would be better to choose one that can arouse students' thoughts from diverse viewpoints, in particular, an issue that is related to their daily-life experiences (Newman et al. 1995). For instance, one possible issue for a health course could be child obesity. The teacher can first provide a video that presents the child obesity problem, so that the students can learn the basic knowledge and cases of child obesity at home. Additionally, the teacher can also prepare several guidelines to help collect evidence or make observations in their daily-life environment before engaging them in discussion in the classroom, such as the cases of their friends', relatives' or neighbors' irregular lifestyle or diet of fast food, as well as the cases reported in the newspaper or on the TV news. The teacher can further encourage the students to find solutions to address the problem. Therefore, after class, students can think of more methods to solve the problem of obesity and apply them in their own lives.

Many issues can be used in issue-quest learning, from social science to civics issues. For instance, in a civics class, the teacher can encourage the students to investigate the issue of diverse family formation and use issue quest as a learning method to collect information on the Internet, take photos, and interview peers or neighbors using their mobile devices before conducting group discussion. The teacher can also ask the students to upload their evidence and report questions they propose to the designated platform for sharing their opinions.

Another example of issue-quest learning is the issue of nuclear power in elementary school social studies courses (Hwang et al. 2008). Taking this issue as an example, in a seamless flipped learning activity, students are asked to watch relevant videos at home via their mobile devices and take notes or annotations on the videos. In the class at school, the teacher raises an issue, "Should we support nuclear power?" Based on this issue, several questions can be proposed in the discussion, such as "How many nuclear power plants are there in Taiwan?", "What is the concept of nuclear power and what is its efficiency?", "What advantages and disadvantages do nuclear power plants bring?", and "Do you support nuclear power?" With the help of mobile and wireless communication technologies, students can take photos in their daily-life environment as well search for additional information on the Internet to support their ideas presented in the classroom. Via this cycle of issue comprehending as well as information collecting, abstracting, and organizing, students' critical thinking, problem-solving, and communication abilities could be promoted.

\section{Application and discussion of knowledge construction tools}

Knowledge construction tools or Mindtools are those tools that assist students to construct and organize knowledge and to develop critical thinking (Jonassen 1996; 
Jonassen et al. 1998). A learning activity with knowledge construction can lead students to review the learning content and conduct meaningful learning to organize their prior and new knowledge.

Based on the categories suggested by researchers, there are seven divisions: databases, semantic networks, spreadsheets, expert systems, system modeling tools, microworlds, and intentional information search engines (Jonassen 1999). In this paper, two representative knowledge construction tools, concept maps and expert systems, are presented. Concept maps provide students with a visualized tool to organize knowledge by drawing the relationship between the concepts in the learning content. Expert systems can be a knowledge construction tool since the implementation of an expert system relies on collecting and organizing domain knowledge or expertise for solving problems or making decisions (Hwang et al. 2014a). For instance, to develop a medical expert system, students need to collect the knowledge related to symptoms and treatments of the target diseases for building the knowledge base that can be used to provide suggestions or prescriptions based on the symptoms of a patient.

While conducting a learning activity with knowledge construction tools, teachers need to make sure if the knowledge feature is suitable for integrating knowledge construction tools into the teaching activity. Different knowledge construction tools could only be suitable for dealing with specific types of knowledge. The following illustrative examples show when to adopt concept maps and grid-based knowledge construction tools in school settings; that is, concept maps can be used to organize the relationship between concepts from a macro view, while grid-based tools can be used to compare the features of learning targets from a micro view, as suggested by Hwang et al. (2014b).

Figure 3 is an example using concept mapping as a knowledge construction tool at an elementary school. In the natural science course, students are expected to know the features and ecology of butterflies. In the seamless flipped learning

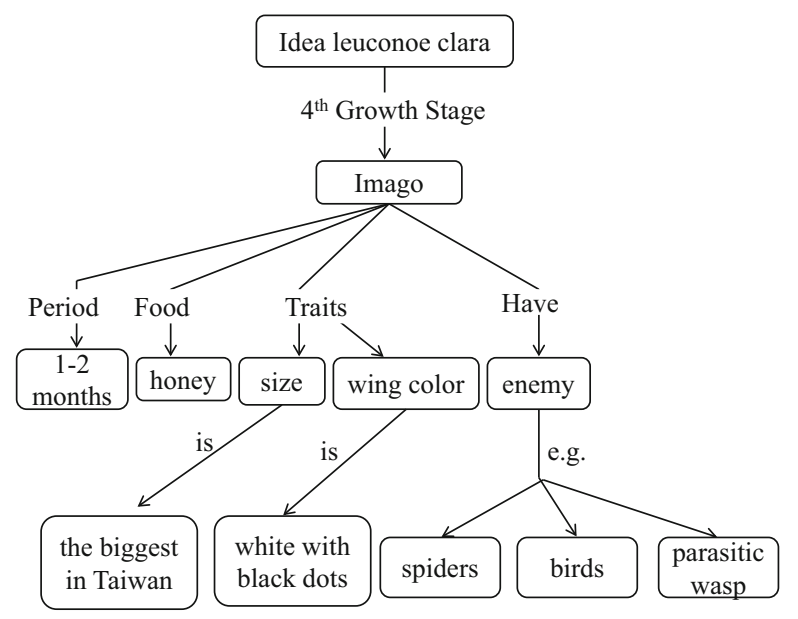

Fig. 3 Illustrative example of a concept map for the butterfly lifecycle 
activity, they watch videos at home and observe butterfly ecology in a butterfly garden. They are then asked to draw a concept map to organize the knowledge of butterflies based on what they have learned from the videos and their observations in the field. Following that, they share their concept maps with peers and have a discussion in the classroom. Such a learning strategy allows students to have a whole picture of the learning topic.

In addition to helping students organize knowledge, concept mapping can also help them think beyond the existing concepts and provide different thinking connections. Hence, a more creative concept framework can be produced through the process of students' visualization of knowledge organization (Fatemeh et al. 2011). Gu et al. (2014) indicated that the interaction among peers, advisors, and experts would have an influence on creativity, with peers as well as advisors having a significant influence on students' creativity. Wu et al. (2014) proposed three key elements affecting college students' creativity development: establishment of a proper stimulus from the environment to activate the social environment, building knowledge suitable for this generation, and infusion of diverse creativity education related to the students' daily lives.

Another example is the grid-based knowledge acquisition tool used in a plant recognition course in an elementary school, as shown in Table 1. This kind of table is called a repertory grid (Chu et al. 2010; Hwang et al. 2013; Kelly 1995). The first row represents the plants that students need to compare, and the first and last columns represent the two opposite traits of the plants, such as the leaf shape. A 5 -scale rating scheme is used to represent the relation of the plants' traits, where 1 means that an object belongs to the trait in the first column and 5 means that it belongs to the trait in the last column.

As shown in Table 1, the first and last columns show the opposite traits of the plants, such as the long and thin leaf shape and flat and round leaf shape. The five columns in the middle are used to fill in the level of the traits of each plant. For instance, the leaf shape of Lalang grass is long and thin so the corresponding grid should be written as 1, whereas the leaf shape of Indian almond is flat and round so the corresponding grid should be written as 4 . With the help of mobile and wireless concision technologies, students can use such a grid to organize the traits of the plants learned from the videos or observed in the field, followed by further discussion in class.

Table 1 Illustrative example of a repertory grid for describing the plants on a school campus

\begin{tabular}{lllllll}
\hline Trait & $\begin{array}{l}\text { Lalang } \\
\text { grass }\end{array}$ & $\begin{array}{l}\text { Variegated } \\
\text { leaf croton }\end{array}$ & Cuphea & $\begin{array}{l}\text { Indian } \\
\text { almond }\end{array}$ & $\begin{array}{c}\text { Money } \\
\text { tree }\end{array}$ & Opposite \\
\hline $\begin{array}{c}\text { Leaf shape long and } \\
\text { thin }\end{array}$ & 1 & 2 & 2 & 4 & 2 & $\begin{array}{c}\text { Leaf shape flat and } \\
\text { round }\end{array}$ \\
$\begin{array}{c}\text { Perfectly smooth } \\
\text { leaf edge }\end{array}$ & 1 & 1 & 4 & 1 & 1 & $\begin{array}{c}\text { The leaf edge has } \\
\text { deep indents }\end{array}$ \\
$\begin{array}{c}\text { The leaf vein has } \\
\text { few branches }\end{array}$ & 5 & 3 & 2 & 2 & 3 & $\begin{array}{c}\text { The leaf vein has } \\
\text { many branches }\end{array}$ \\
\hline
\end{tabular}




\section{Using application software or supplementary materials for extension courses and discussion}

Extension course learning means providing students with application software (e.g., educational systems) or additional sources (e.g., educational websites) related to the learning content as a supplement or extension of the course (Walton et al. 2005). In the setting of a seamless flipped learning environment, teachers need to focus on the relationships between the learning content, additional learning sources or application software, and the real-world contexts, meaning that the provision of the additional learning sources or application software can help students acquire extensive knowledge of the course content and connect the knowledge to real-world contexts. In this way, students can try to apply and extend their knowledge in the class (Zurita et al. 2003).

For instance, in an earth science course at a high school, students need to gain basic knowledge of astronomy before the class. In the class, students use the mobile application, Google Sky Map, to observe the sky and complete the learning sheets in groups, as shown in Fig. 4. In addition, teachers can further ask the students to observe the specified constellations after the class and share their findings in the learning system.

\section{Problem-based learning}

The purpose of problem-based learning is to engage students in exploration activities and to use their prior knowledge as well as the information learned in the activity to construct knowledge (Şendağ and Ferhan 2009). Educators have
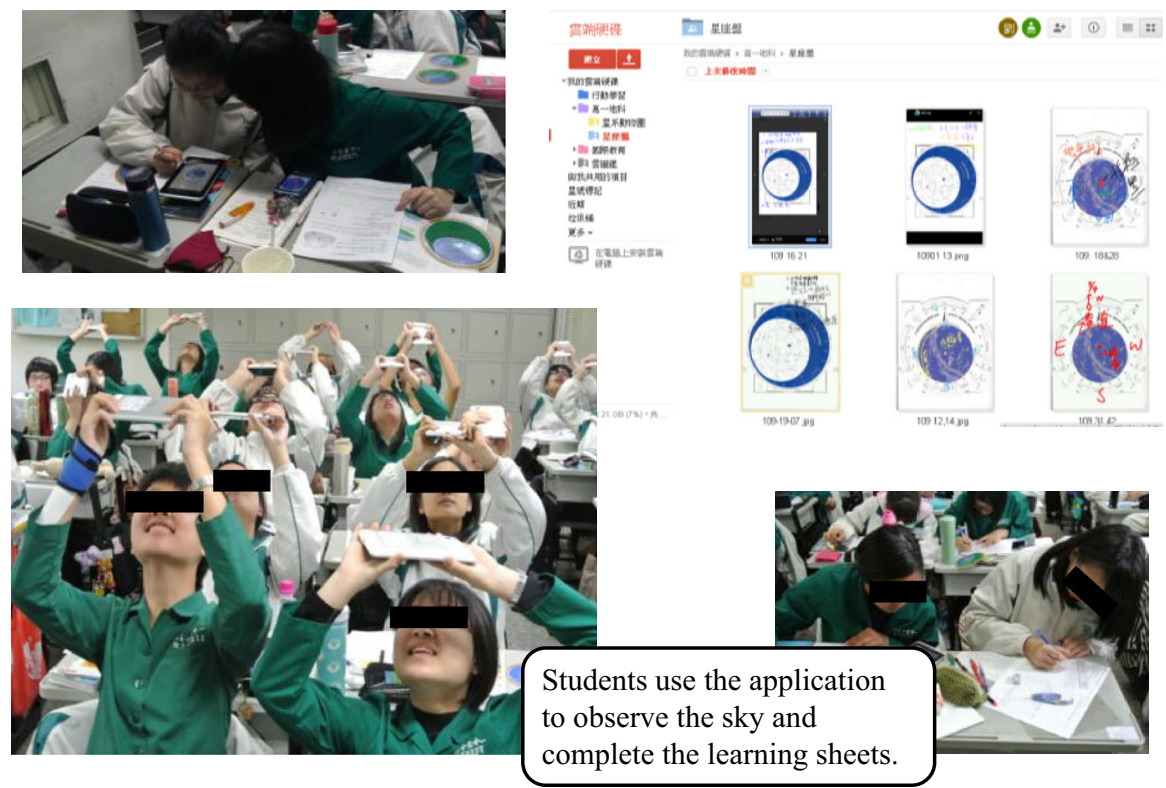

Fig. 4 Students conduct an extension course learning activity 
recognized problem-based learning activities as an important learning strategy that encourages students to conduct higher order thinking and which promotes students' skills besides subject knowledge (Lazakidou and Retalis 2010). In such a learning activity, students construct knowledge, solve problems, and reflect in a contextual and non-structured environment (Hoffman and Ritchie 1997). This means that the purpose of the learning activity is not to provide the answers to the problems, but rather is a process of finding the solution to the problems. The problems can be solved in various ways using different information. Therefore, while designing a problem-based learning activity, teachers need to understand if the learning content is suitable for providing students with a chance to find the answer, and students can have different answers based on the information they find. In such a learning environment, in order to find the solution to the problem, students go through the process of critical thinking and try to define problems, analyze events, find solutions, and make decisions in a contextual environment.

In seamless flipped learning activities for problem solving, teachers can arrange a learning task related to a real-world problem to be coped with (e.g., the pollution in a river beside the school) and ask students to collect information in the real-world environment (e.g., taking photos of the river) or search for information on the web (e.g., using Google Maps) after watching a video about environmental pollution at home. Following that, the students can discuss with team members possible solutions to the problem. Later, in class time, they can present their findings and solutions and modify their solutions after receiving feedback from peers and teachers.

\section{Individual project-based learning}

Project-based learning is a learning activity that aims to complete a project product, which can be either collaborative or individual. The learning activity is student centered. Students need to go through a series of challenges and find solutions to gain knowledge and boost their thinking, problem solving, planning, decision making, and production of the project product (Zhang et al. 2010). Teachers need to consider the difficulty and complexity of the mission. It should be completed alone in a limited period of time.

Individual projects are usually much easier. For example, in an English course, students learn some new vocabulary by watching videos before class. They are then required to use the vocabulary to write a short essay and make a video by recording some real-world contexts related to the vocabulary. Later, they are asked to share the videos with peers in class. Another example is a learning activity in an electronics class. Students are asked to complete the connection of an electronic circuit, record the process using their mobile device, and share it with their peers, as shown in Fig. 5. The teacher can also ask the students to observe the related electronic devices in their daily-life environment and take photos for further in-class discussions. 

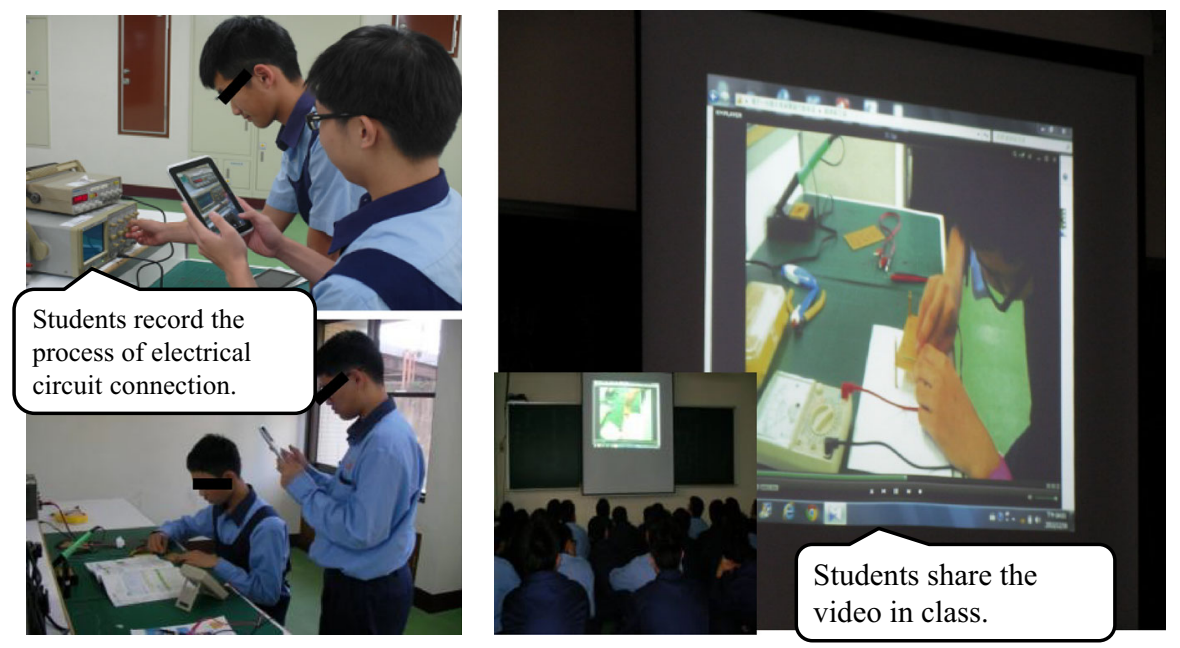

Fig. 5 Illustrative example of Individual project-based learning

\section{Collaborative project-based learning and knowledge sharing}

Collaborative project-based learning is different from individual projects. It focuses on the importance of collaboration in the whole learning activity. During the process of collaborative project-based learning, students need to divide the work and cooperate to complete the learning missions (Chang and Lee 2010). Therefore, teachers need to consider the complexity of the mission while designing the teaching activity. Cross-subject project-based learning can be taken into consideration to let the students gain knowledge and learn teamwork skills.

There are many kinds of common collaborative project-based learning, for instance, project presentations, digital storytelling, and project products. Take project presentations as an example. Students need to divide the work of searching for information, organizing, and inferring to conduct the learning activity. As for digital storytelling, they need to write, shoot, and edit a video based on a certain topic. Project products require students to work together to complete a large product, such as a large work of art or an experiment. In such a learning activity, the students use their strengths to help their peers complete the activity. Therefore, they can not only gain the knowledge of a certain subject but also learn work division, supervision, teamwork, and communication skills during the learning process. For instance, a geography information system is used in a high school to let students analyze the living environment and plan a field trip. Before the field trip, students watch the video to learn how to use the geography information system and some basic geography knowledge. In the classroom, they need to discuss with team members and develop a plan to complete the digital storytelling project (e.g., making a video to introduce their hometown). Later, on the field trip, they take photos and videos and interview people based on the plan. Following that, they 


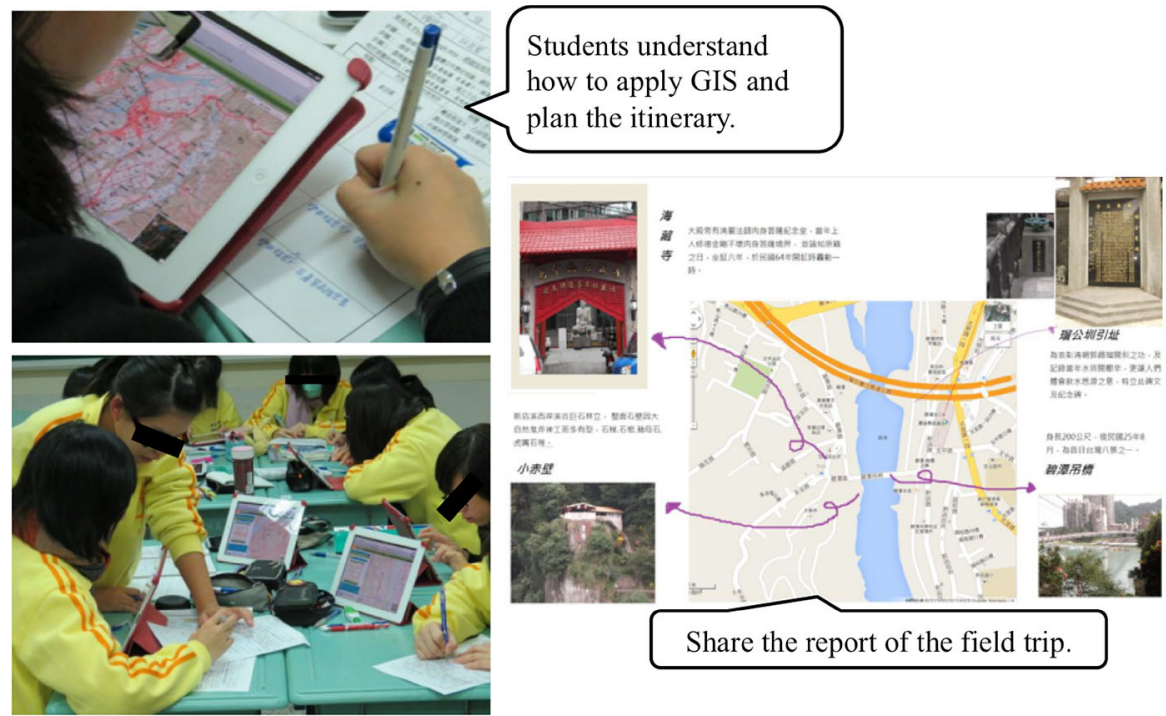

Fig. 6 Illustrative example of project-based learning

produce the video and present it to peers and teachers in the class, as shown in Fig. 6.

\section{Peer assessment}

Peer assessment is considered to be a learning activity that can stimulate students' higher order thinking ability no matter whether in the past or now. By peer assessment, students can understand the teacher's point of grading and hence reflect on their work. The most important point is to let students think from the teacher's point of view while giving grades, which can help them understand the content and meaning of knowledge (Hsia et al. 2015). Several previous studies have shown that peer assessment can increase students' learning effects and the understanding of knowledge as well as promote their evaluation ability (Hwang et al. 2014; Nicolaidou 2013).

Peer assessment can accompany project-based activities. For instance, teachers can let students give grades for storytelling videos. Before starting to make a story video, teachers need to give students rubrics. The point of the rubrics is not to remind them of the scores, but rather to let them reflect on and improve their own projects (Hung et al. 2012).

While designing a teaching activity with peer assessment, the teacher's most important concern is to provide the students with a complete evaluation rubric. For instance, Table 2 shows an illustrative example of a rubric for a poster design activity (Lai and Hwang 2015). During the evaluation of the poster design, the teacher needs to offer the items and rules for grading and let the students know the requirements of each dimension. These requirements are not just a reference for the 
Table 2 Rubric of poster design for peer assessment (Lai and Hwang 2015)

\begin{tabular}{|c|c|c|c|}
\hline \multirow[t]{2}{*}{ Dimension } & \multicolumn{3}{|l|}{ Rating } \\
\hline & 3 & 2 & 1 \\
\hline Word & $\begin{array}{l}\text { The size of the heading is } \\
\text { large and striking } \\
\text { The size of the content is } \\
\text { middle type } \\
\text { The text has rich } \\
\text { decoration }\end{array}$ & $\begin{array}{l}\text { The size of the heading is } \\
\text { not large enough } \\
\text { The size of the content } \\
\text { looks the same as the } \\
\text { heading } \\
\text { The text has some } \\
\text { decoration }\end{array}$ & $\begin{array}{l}\text { The size of the heading is too } \\
\text { small } \\
\text { The size of the content is too big } \\
\text { The text has no decoration }\end{array}$ \\
\hline Space & $\begin{array}{l}\text { The distribution of the } \\
\text { space is fine } \\
\text { The font size of the main } \\
\text { content is proper }\end{array}$ & $\begin{array}{l}\text { The distribution of the } \\
\text { space is not good enough } \\
\text { The font size of the main } \\
\text { content is not big enough }\end{array}$ & $\begin{array}{l}\text { The distribution of the space is } \\
\text { messy } \\
\text { The font size of the main content } \\
\text { is too small }\end{array}$ \\
\hline Color & $\begin{array}{l}\text { This poster is colorful } \\
\text { The adopted colors make } \\
\text { the main content } \\
\text { striking }\end{array}$ & $\begin{array}{l}\text { This poster only contains } \\
2-3 \text { colors } \\
\text { The adopted colors do not } \\
\text { make the main content } \\
\text { striking }\end{array}$ & $\begin{array}{l}\text { This poster is boring } \\
\text { The adopted colors make the } \\
\text { poster messy }\end{array}$ \\
\hline Theme & $\begin{array}{l}\text { All of the poster content } \\
\text { is consistent with the } \\
\text { theme } \\
\text { The heading is highly } \\
\text { related to the theme }\end{array}$ & $\begin{array}{l}\text { Part of the poster content is } \\
\text { related to the theme } \\
\text { The heading is partially } \\
\text { relevant to the theme }\end{array}$ & $\begin{array}{l}\text { All of the content, including its } \\
\text { heading, is not relevant to the } \\
\text { theme }\end{array}$ \\
\hline
\end{tabular}

students, but also boost the process of evaluation. Students can consider if their own products meet the requirements.

In a seamless flipped learning activity, the peer assessment strategy is employed with other strategies, such as project-based learning to engage students in critical thinking and making reflections. For example, considering the digital storytelling project with peer assessment, the students might need to collect more data in the field and discuss more in the class after receiving the ratings and comments from peers.

\section{Peer competition or gaming}

Competition is a teaching strategy widely adopted by teachers in educational settings. Through such a competitive strategy, students' learning motivation and a sense of honor are enhanced, which can inspire their desire to learn (Hwang et al. 2012). While planning competitive activities, teachers need to consider how to integrate the learning contents into the competition. This requires thorough teaching plans to let the students learn while playing so that the focus of learning is not missed (Moreno 2012).

In a seamless flipped learning activity, the competitive tasks can be conducted in the classroom or field after the students watch the instructional video at home. 
Moreover, the competitive tasks can be relevant to the video content or the realworld context. For example, in a seamless flipped learning activity with peer competition, the students might need to find answers by observing some real-world learning targets in an ecology park.

\section{Potential research issues of seamless flipped learning}

The seamless flipped learning scenarios that enable students to learn across contexts using mobile and wireless communication technologies raise many research questions from the aspects of pedagogy and technology. Some of the questions are listed as follows:

(1) How can we help teachers implement effective seamless flipped learning activities to present the potential value of using mobile wireless communication technologies to support students to learn across various learning spaces?

(2) How can we foster students' self-learning ability, such that they can benefit from the seamless flipped learning activities? What are the roles of parents in conducting seamless flipped learning?

(3) How do we employ emerging technologies, such as cloud computing, learning analytics, and augmented reality, to facilitate seamless flipped learning?

(4) What are the barriers to be overcome when we are promoting the notion of seamless flipped learning in school settings? How do we build teachers' beliefs in seamless flipped learning?

(5) What are the new digital-divide and equity issues when seamless flipped learning has been widely implemented in school settings?

(6) What can we do to implement better learning management systems to support seamless flipped learning from both the aspects of teachers' and students' needs? What are the roles of artificial intelligence and sensing technologies in developing more effective seamless flipped learning management systems?

(7) What are the impacts of different seamless flipped learning strategies on students' learning outcomes? What are the factors affecting their learning outcomes?

(8) What are the benefits of different seamless flipped learning strategies? Can they promote students' higher order thinking performance, such as problemsolving skills, critical thinking, and creative performance?

These questions as well as other relevant issues will need to be discussed when seamless flipped learning is widely adopted across the world. In recent years, mobile learning and flipped learning have been promoted by several countries and regions. It is predicted that more and more countries will try to implement these innovative learning approaches. On the other hand, fostering students' higher order thinking has been emphasized by educators for decades and has been receiving more attention in recent years. Therefore, engaging students in seamless flipped learning, 
which emphasizes self-regulated and across-context learning to foster the higher order thinking competences of students, will eventually be widely accepted. That is, it is necessary to value the importance of seamless flipped learning and start investigating those relevant issues.

Acknowledgments This study is supported in part by the National Science Council of the Republic of China under contract numbers NSC 101-2511-S-011 -005 -MY3 and NSC 102-2511-S-011 -007 -MY3.

\section{References}

Abeysekera, L., \& Dawson, P. (2014). Motivation and cognitive load in the flipped classroom: definition, rationale and a call for research. Higher Education Research \& Development, 34, 1-14. doi:10.1080/ 07294360.2014 .934336$.

Anderson, W., \& Krathwohl, D. R. (2001). A taxonomy for learning, teaching, and assessing: A revision of Bloom's educational objectives. NY: Longamn.

Association of Flipped Learning Network. (2014). What is flipped learning? Retrieved July 15, 2013, from http://fln.schoolwires.net//site/Default.aspx?PageID=92.

Bergmann, J., Overmyer, J., \& Wilie, B. (2011). The flipped class: Myths vs. reality. The Daily Riff,. doi:10.1037/00220663.81.3.329.

Bergmann, J., \& Sams, A. (2012). Flip your classroom: Reach every student in every class every day. OR: International Society for Technology in Education.

Bishop, J. L., \& Verleger, M. A. (2013, June). The flipped classroom: A survey of the research. In ASEE National Conference Proceedings, Atlanta, GA.

Bloom, B. S. (1994). Reflections on development retrospective (pp. 1-8). Chicago, IL: The National Society for the Study of Education.

Chang, L. C., \& Lee, G. C. (2010). A team-teaching model for practicing project-based learning in high school: Collaboration between computer and subject teachers. Computers \& Education, 55(3), 961-969.

Chao, C. Y., Chen, Y. T., \& Chuang, K. Y. (2015). Exploring students' learning attitude and achievement in flipped learning supported computer aided design curriculum: A study in high school engineering education. Computer Applications in Engineering Education, 23, 422-431.

Chu, H. C., Hwang, G. J., \& Tsai, C. C. (2010). A knowledge engineering approach to developing mindtools for context-aware ubiquitous learning. Computers \& Education, 54(1), 289-297.

Dwyer, C. P., Hogan, M. J., \& Stewart, I. (2014). An integrated critical thinking framework for the 21st century. Thinking Skills and Creativity, 12, 43-52.

Eggen, P., \& Kauchak, D. (2007). Educational psychology: Windows on classrooms (7th ed.). Upper Saddle River, NJ: Merrill/Prentice Hall.

Fatemeh, H., Ahmad, K., \& Mohammad, D. M. (2011). ICMAP: An interactive tool for concept map generation to facilitate learning proves. Procedia Computer Science, 3, 524-529.

Fautch, J. M. (2015). The flipped classroom for teaching organic chemistry in small classes: Is it effective? Chemistry Education Research and Practice, 16(1), 179-186.

Felder, R. M., \& Brent, R. (2003). Learning By Doing. Chemical Engineering Education, 37(4), $282-283$.

Finke, R. A., Ward, T. B., \& Smith, S. M. (1992). Creative cognition. Cambridge, MA: MIT Press.

Francl, T. J. (2014). Is flipped learning appropriate? (pp. 119-128). Claytin: Publication of National University.

Gilboy, M. B., Heinerichs, S., \& Pazzaglia, G. (2015). Enhancing student engagement using the flipped classroom. Journal of nutrition education and behavior, 47(1), 109-114.

Glassner, A., Weinstock, M., \& Neuman, Y. (2005). Pupils' evaluation and generation of evidence and explanation in argumentation. British Journal of Educational Psychology, 75, 105-118.

Good, T., \& Brophy, J. (2003). Looking in classrooms (9th ed.). Boston: Allyn and Bacon.

Gu, J., Zhang, Y., \& Liu, H. (2014). Importance of social capital to student creativity within higher education in China. Thinking Skills and Creativity, 12, 14-25.

Hoffman, B., \& Ritchie, D. (1997). Using multimedia to overcome the problems with problem based learning. Instructional Science, 25, 97-115. 
Hsia, L. H., Huang, I., \& Hwang, G. J. (2015). A web-based peer-assessment approach to improving junior high school students' performance, self-efficacy and motivation in performing arts courses. British Journal of Educational Technology, 59, 1-15.

Hung, H. T. (2015). Flipping the classroom for English language learners to foster active learning. Computer Assisted Language Learning, 28(1), 81-96.

Hung, C. M., Hwang, G. J., \& Huang, I. (2012). A project-based digital storytelling approach for improving students' learning motivation, problem-solving competence and learning achievement. Educational Technology \& Society, 15(4), 368-379.

Hwang, G. J., Hung, C. M., \& Chen, N. S. (2014a). Improving learning achievements, motivations and problem-solving skills through peer assessment-based game development approach. Educational Technology Research and Development, 62(2), 129-145.

Hwang, G. J., Hung, P. H., Chen, N. S., \& Liu, G. Z. (2014b). Mindtool-assisted in-field learning (MAIL): An advanced ubiquitous learning project in Taiwan. Educational Technology \& Society, 17(2), 4-16.

Hwang, G. J., Sung, H. Y., Hung, C. M., Yang, L. H., \& Huang, I. (2013). A knowledge engineering approach to developing educational computer games for improving students' differentiating knowledge. British Journal of Educational Technology, 44(2), 183-196.

Hwang, G. J., Tsai, P. S., Tsai, C. C., \& Tseng, Judy C. R. (2008a). A novel approach for assisting teachers in analyzing student web-searching behaviors. Computers \& Education, 51(2), 926-938.

Hwang, G. J., Tsai, C. C., \& Yang, Stephen J. H. (2008b). Criteria, strategies and research issues of context-aware ubiquitous learning. Educational Technology \& Society, 11(2), 81-91.

Hwang, G. J., Wu, P. H., \& Chen, C. C. (2012). An online game approach for improving students' learning performance in web-based problem-solving activities. Computers \& Education, 59(4), 1246-1256.

Jonassen, D. H. (1996). Computers in the classroom: Mindtools for critical thinking. Columbus OH: Merrill/Prentice-Hall.

Jonassen, D. H. (1999). Computers as mindtools for schools: Engaging critical thinking (2nd ed.). Upper Saddle River, NJ: Prentice Hall.

Jonassen, D. H., Carr, C., \& Yueh, H. P. (1998). Computers as Mindtools for engaging learners in critical thinking. TechTrends, 43(2), 24-32.

Kamarudin, S. K., Abdullah, S. R. S., Kofli, N. T., Rahman, N. A., Tasirin, S. M., \& Jahim, J. (2012). Communication and teamwork skills in student learning process in the university. Procedia-Social and Behavioral Sciences, 60, 472-478.

Kelly, G. A. (1955). The psychology of personal constructs (Vol. 1). New York: Norton.

Khan. (2015). Let's use video to reinvent education. http://www.ted.com/talks/salman_khan_let_s_use_ video_to_reinvent_education\#t-10820.

Kim, M. K., Kim, S. M., Khera, O., \& Getman, J. (2014). The experience of three flipped classrooms in an urban university: An exploration of design principles. Internet and Higher Education, 22, 37-50.

Kong, S. C., \& Song, Y. J. (2014). The impact of a principle-based pedagogical design on inquiry-based learning in a seamless learning environment in Hong Kong. Educational Technology \& Society, 17(2), 127-141.

Kong, S. C., \& Song, Y. (2015). An experience of personalized learning hub initiative embedding BYOD for reflective engagement in higher education. Computers \& Education, 88, 227-240.

Kuo, F. R., \& Hwang, G. J. (2014). A five-phase learning cycle approach to improving web-based problem-solving performance of students. Educational Technology \& Society, 17(1), 169-184.

Kuo, F. R., Hwang, G. J., Chen, S. C., \& Chen, Sherry Y. (2012). A cognitive apprenticeship approach to facilitating web-based collaborative problem solving. Educational Technology \& Society, 15(4), 319-331.

Lai, C. L., \& Hwang, G. J. (2014). Effects of mobile learning time on students' conception of collaboration, communication, complex problem-solving, meta-cognitive awareness and creativity. International Journal of Mobile Learning and Organisation, 8(3), 276-291.

Lai, C. L., \& Hwang, G. J. (2015). An interactive peer-assessment criteria development approach to improving students' art design performance using handheld devices. Computers \& Education, 85, 149-159.

Lan, Y. F., Tsai, P. W., Yang, S. H., \& Hung, C. L. (2012). Comparing the social knowledge construction behavioral patterns of problem-based online asynchronous discussion in e/m-learning environments. Computers \& Education, 59(4), 1122-1135. 
Lasry, N., Dugdale, M., \& Charles, E. (2014). Just in time to flip your classroom. The Physics Teacher, 52(1), 34-37.

Lazakidou, G., \& Retalis, S. (2010). Using computer supported collaborative learning strategies for helping students acquire self-regulated problem-solving skills in mathematics. Computers \& Education, 54(1), 3-13.

Looi, C. K., Seow, P., Zhang, B. H., So, H. J., Chen, W. L., \& Wong, L. H. (2010). Leveraging mobile technology for sustainable seamless learning: A research agenda. British Journal of Educational Technology, 41(2), 154-169.

Looi, C. K., \& Wong, L. H. (2014). Implementing mobile learning curricula in schools: A programme of research from innovation to scaling. Educational Technology \& Society, 17(2), 72-84.

Milrad, M., Wong, L. H., Sharples, M., Hwang, G. J., Looi, C. K., \& Ogata, H. (2013). Seamless learning: An international perspective on next generation technology enhanced learning. In Z. L. Berge \& L. Y. Muilenburg (Eds.), Handbook of mobile learning (Chapter 9) (pp. 95-108). New York, NY: Routledge.

Moreno, J. (2012). Digital competition game to improve programming skills. Educational Technology \& Society, 15(3), 288-297.

Newman, D. R., Webb, B., \& Cochrane, C. (1995). A content analysis method to measure critical thinking in face-to-face and computer supported group learning. Interpersonal Computing and Technology, 3(2), 56-77.

$\mathrm{Ng}$, W. (2015). Technology integration and the flipped classroom. In: New digital technology in education (pp. 149-169). New York: Springer International Publishing.

Nicolaidou, I. (2013). E-portfolios supporting primary students' writing performance and peer feedback. Computers \& Education, 68, 404-415.

Rooij, S. W. V. (2009). Scaffolding project-based learning with the project management body of knowledge (PMBOK). Computer \& Education, 52(1), 210-219.

Şendağ, S., \& Ferhan, O. H. (2009). Effects of an online problem based learning course on content knowledge acquisition and critical thinking skills. Computers \& Education, 53(1), 132-141.

Simonton, D. K., \& Ting, S.-S. (2010). Creativity in Eastern and Western civilizations: The lessons of historiometry. Management and Organization Review, 6, 329-350.

Song, Y. J. (2014). "Bring Your Own Device (BYOD)" for seamless science inquiry in a primary school. Computers \& Education, 74, 50-60.

Spencer, D., Wolf, D., \& Sams, A. (2011). Are you ready to flip? Retrieved July, 18, 2013.

Stone, B. B. (2012). Flip your classroom to increase active learning and student engagement. In: Proceedings from 28th annual conference on distance teaching and learning, Madison, WI

Trilling, B., \& Fadel, C. (2009). 21st century skills: Learning for life in our times. San Francisco, CA: Jossey-Bass.

Tsai, P. S., Hwang, G. J., Tsai, C. C., Hung, C. M., \& Huang, I. (2012). An electronic library-based learning environment for supporting web-based problem-solving activities. Educational Technology \& Society, 15(4), 252-264.

Tucker, B. (2012). The flipped classroom. Education Next, 12(1), 82-83.

van Gelder, T. (2005). Teaching critical thinking: Some lessons from cognitive science. College Teaching, 53, 41-46.

Walton, G., Childs, S., \& Blenkinsopp, E. (2005). Using mobile technologies to give health students access to learning resources in the UK community setting. Health Information \& Libraries Journal, 22, 51-65.

Wong, L.-H. (2012). A learner-centric view of mobile seamless learning. British Journal of Educational Technology, 43(1), E19-E23.

Wong, L. H., Chai, C. S., Aw, G. P., \& King, R. B. (2015a). Enculturating seamless language learning through artifact creation and social interaction process. Interactive Learning Environments, 23(2), $130-157$.

Wong, L. H., Chen, W., \& Jan, M. (2012). How artefacts mediate small-group co-creation activities in a mobile-assisted seamless language learning environment? Journal of Computer Assisted learning, 28(5), 411-424.

Wong, L.-H., Chen, W., Looi, C.-K., \& Zhang, B. (2010). Analysis of attributes of mobile learning activities: two case studies of m-learning design. China Educational Technology, 2010(2), 7-15.

Wong, L.-H., \& Looi, C.-K. (2011). What seams do we remove in mobile-assisted seamless learning? A critical review of the literature. Computers \& Education, 57(4), 2364-2381. 
Wong, L. H., Milrad, M., \& Specht, M. (2015b). Seamless learning in the age of mobile connectivity. Singapore: Springer.

Woolfolk, A. (2004). Educational psychology (9th ed.). Boston, MA: Allyn \& Bacon.

Wu, H. Y., Wu, H. S., Chen, I. S., \& Chen, H. C. (2014). Exploring the critical influential factors of creativity for college students: A multiple criteria decision-making approach. Thinking Skills and Creativity, 11, 1-21.

Zhang, B., Looi, C. K., Seow, P., Chia, G., Wong, L. H., Chen, W., \& Norris, C. (2010). Deconstructing and reconstructing: Transforming primary science learning via a mobilized curriculum. Computers \& Education, 55(4), 1504-1523.

Zurita, G., Nussbaum, M., \& Shaples, M. (2003). Encouraging face-to-face collaborative learning through the use of handheld computers in the classroom. In L. Chittaro (Ed.), Human-computer interaction with mobile devices and services (Vol. 2795, pp. 193-208). Berlin: Springer-Verlag, Berlin.

Dr. Gwo-Jen Hwang is a Chair Professor in the Graduate Institute of Digital Learning and Education, National Taiwan University of Science and Technology, Taiwan. His research interests include mobile and ubiquitous learning, digital game-based learning, artificial intelligence in education, and web-based learning.

Ms. Chiu-Lin Lai is a PhD student at the Graduate Institute of Applied Science and Technology, National Taiwan University of Science and Technology, Taiwan. Her research interests include computer-assisted learning and mobile learning.

Ms. Siang-Yi Wang is an undergraduate student at the Graduate Institute of Digital Learning and Education, National Taiwan University of Science and Technology, Taiwan. Her research interests include computer-assisted language learning and digital game-based learning. 